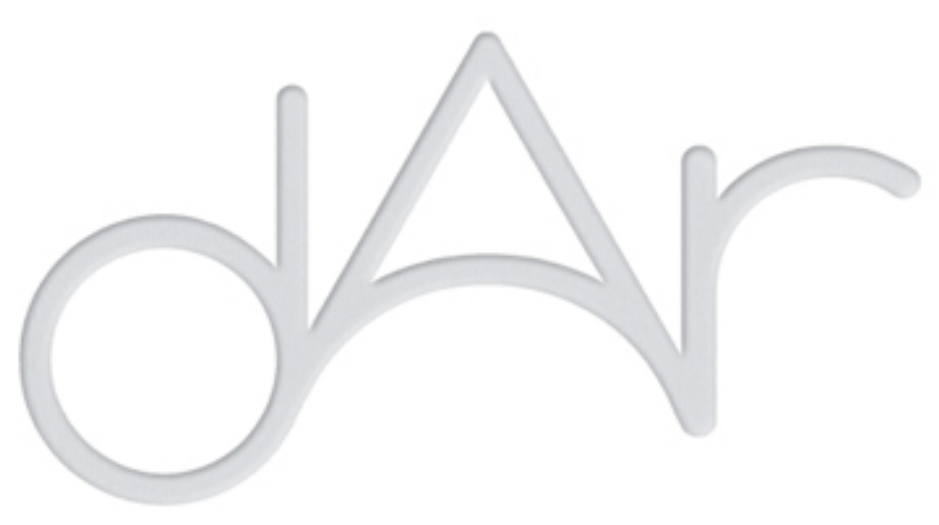

Corpo e água: os banhos públicos em Portugal na Idade Média

Autor(es): Trindade, Luísa

Publicado por: Centro de Estudos em Arqueologia, Artes e Ciências do Património

URL

persistente: URI:http://hdl.handle.net/10316.2/39309

DOI: $\quad$ DOI:http://dx.doi.org/10.14195/2182-844X_2_14

Accessed : $\quad$ 19-May-2017 14:51:43

A navegação consulta e descarregamento dos títulos inseridos nas Bibliotecas Digitais UC Digitalis, UC Pombalina e UC Impactum, pressupõem a aceitação plena e sem reservas dos Termos e Condições de Uso destas Bibliotecas Digitais, disponíveis em https://digitalis.uc.pt/pt-pt/termos.

Conforme exposto nos referidos Termos e Condições de Uso, o descarregamento de títulos de acesso restrito requer uma licença válida de autorização devendo o utilizador aceder ao(s) documento(s) a partir de um endereço de IP da instituição detentora da supramencionada licença.

Ao utilizador é apenas permitido o descarregamento para uso pessoal, pelo que o emprego do(s) título(s) descarregado(s) para outro fim, designadamente comercial, carece de autorização do respetivo autor ou editor da obra.

Na medida em que todas as obras da UC Digitalis se encontram protegidas pelo Código do Direito de Autor e Direitos Conexos e demais legislação aplicável, toda a cópia, parcial ou total, deste documento, nos casos em que é legalmente admitida, deverá conter ou fazer-se acompanhar por este aviso.

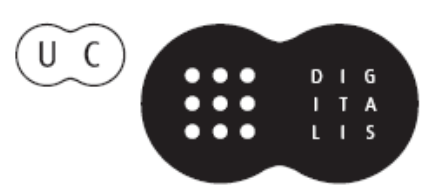




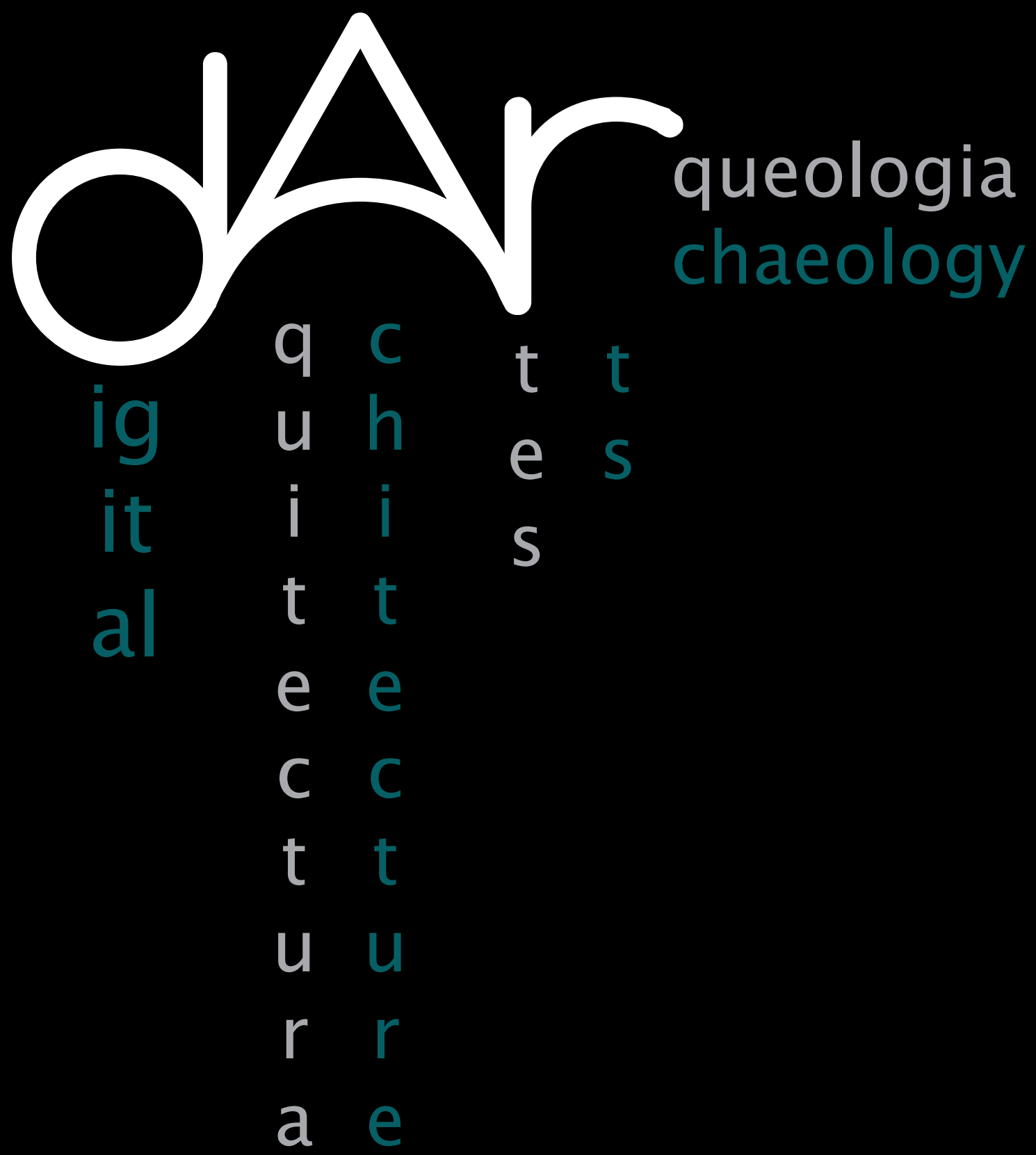




\title{
CORPO E ÁGUA: OS BANHOS PÚBLICOS EM PORTUGAL NA IDADE MÉDIA
}

\author{
Luísa Trindade* \\ CES - Centro de Estudos Sociais \\ FLUC - Faculdade de Letras da Universidade de Coimbra
}

\section{RESUMO}

Afastado há muito o mito da extinção da prática do banho na ldade Média Ocidental, a sua expressão na sociedade portuguesa permanece, todavia, praticamente desconhecida. De facto, o conjunto de referências documentais que atesta a existência de banhos públicos na maioria das cidades e vilas, não tem sido suficiente para suscitar de forma significativa o estudo desta temática. É neste contexto que, assumindo um claro partido exploratório, o presente artigo procura sistematizar algumas questões: a expressão material destes equipamentos (estrutura, eventual especificidade arquitectónica), mas também a forma como o banho marcou as vivências quotidianas, generalizadamente aceite e praticado pelas suas qualidades terapêuticas ou, sob apertada vigilância e progressiva condenação, vivenciado como momento lúdico de marcada sociabilidade.

Palavras-chave: Banhos públicos, Idade Média, urbanidade

\begin{abstract}
Although the disappearance of bathing in the Middle Ages is for long assumed as a myth, the real expression of this practise in Portuguese society remains, however, largely unknown. In fact, the substantial number of written references attesting the existence of public baths in the majority of Portuguese medieval towns, has not been sufficient to encourage any significant research on the subject. Thus, assuming a clear exploratory approach, this paper aims at investigate some particular topics: the material expression of these equipment (structure, hypothetic architectural specificity), but also how bathing marked 'everyday experiences, either as widely accepted and practiced by its therapeutic qualities or, under close surveillance and progressive criticisms, experienced as a moment of particular pleasure and sociability.
\end{abstract}

Keywords: Public baths, Middle Ages, urbanity 
Tomar banho raramente foi (ou é) apenas um gesto utilitário, exclusivamente destinado à limpeza do corpo. Ritual voluntário e espontâneo ou forçado e imperativo, popular e simples ou sofisticado e complexo, dota-se, no decorrer dos tempos, de contornos e significados múltiplos.

Razão suficiente para que o tema, embora circunscrito à realidade portuguesa tardo medieval, fosse escolhido para apresentar ao colóquio O Corpo Através da Imagem, por convocar esse mesmo corpo num vasto espectro de dimensões, todas elas diretamente compreendidas no âmbito temático da discussão pretendida: vida e morte, corpo e alma, costumes e tecnologias, intimidade e desejo, medos e fantasmas.

Acrescia, todavia, que este encaixe constituía a oportunidade de finalmente tratar um tema cuja curiosidade resultava em grande parte de um aparente paradoxo: embora os banhos públicos sejam referências habituais na documentação medieval relativa a qualquer cidade ou vila, independentemente da sua dimensão ou nível de urbanidade, continuam praticamente por tratar pela já tão vasta e diversificada historiografia medieval portuguesa. Em síntese, apesar da sua popularidade à época, permanecem hoje quase totalmente desconhecidos.

Como tal paradoxo não seria certamente acidental, o investimento neste tema teve implícito, desde o início, um risco óbvio: a previsível dificuldade em encontrar respostas para as muitas questões que o tema suscita. Apesar disso e mesmo que com resultados aquém das expectativas, como tantas vezes acontece, destaco aqui alguns aspetos que me parecem justificar amplamente este investimento:

- uma leitura do panorama português à luz dos resultados da historiografia internacional:

- reforçar o abandono definitivo de diversos mitos pelo reposicionamento da problemática de base;

- uma explicação para o desaparecimento dos banhos medievais, tanto mais inusitado quanto equipamentos de função similar consideravelmente mas antigos, romanos ou islâmicos, lograram sobreviver.

Embora nem sempre seja fácil traçar uma linha nítida entre os diferentes tipos de banho, termais e correntes, sobretudo quando os primeiros se inscrevem no espaço urbano, importa sublinhar que não são as águas termais, as Aquae Calidae, conhecidas e exploradas desde a antiguidade, o enfoque principal do presente texto. De forma ininterrupta e por toda a Europa, estes mananciais de águas quentes e minerais, especializados na cura ou alívio de diferentes males, continuaram a ser amplamente procurados ${ }^{1}$ e, em muito casos, objecto de ampla divulgação.

As termas de Baiae e Pozzuoli, na Baía de Nápoles, detalhadamente descritas e iluminadas no poema de Petrus de Ebulo, escrito nos inícios do século XIII, são disso exemplo paradigmático. No caso

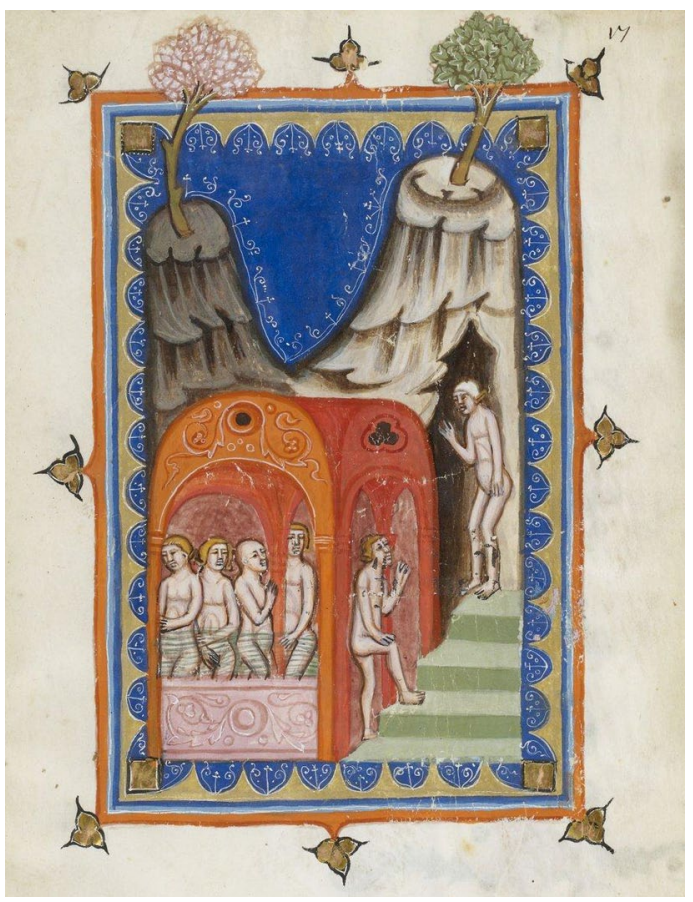

Fig. 1 - As termas de Pozzuoli (Nápoles). Petrus de Ebulo, De balneis puteolanis, Paris, Bibliothèque nationale de France (BnF), Département des manuscrits, Latin 8161, fl. 35. 
português, o exemplo mais conhecido continua a ser o das termas romanas de S. Pedro do Sul (Frade \& Moreira, 1992), onde Afonso Henriques, após o desastre de Badajoz ou o "infortúnio do rei", como ficou conhecido pelas crónicas, convalesceu entre setembro e novembro de 1169 (Mattoso, 2007, p. 305). ${ }^{2}$

Na realidade, independentemente da forma (vapor ou imersão) e da frequência, é o uso do banho como prática cultural, preceito de higiene e espaço/tempo de convivialidade lúdica, que pretendo explorar. Sobretudo na sua vertente urbana, pública e colectiva.

Nessa análise, embora não esquecendo condicionantes físicas tão óbvias como as climatéricas, geológicas e tecnológicas - do frio versus calor à abundância ou escassez de água, passando pelos avanços e possibilidades da engenharia hidráulica é a moldura cultural aquela que, de forma mais fundamentada, parece explicar a sua maior ou menor presença e uso.

No âmbito peninsular ou de forma ainda mais circunscrita, no território hoje português, tal poderia traduzir, como sugestivamente resumiu Oliveira Marques, a diferença entre o "Suleimão do sul", neto de muçulmanos, e o "Gumersindo do norte", descendente de rudes asturienses (Marques,
1974, p. 88). Mesmo que subjacente a "Suleimões e Gomersindos" e matizando o fosso entre ambos se encontre o cimento romano, tão significativo a norte - Chaves $^{3}$ e Braga são prova disso - quanto a sul, onde estruturas domésticas e públicas ombreiam em sofisticação e dimensão.

Se na Península lbérica a desestruturação do Império romano enquanto unidade político-administrativa e cultural implicou um significativo recuo da prática do banho, interrompendo-se em alguma regiões, circunscrevendo-se a estruturas palatinas e eclesiásticas, sobretudo episcopais, noutras, a verdade é que não seria preciso esperar muito para que reaparecesse com nova intensidade. Sob o domínio islâmico, o banho 4 foi uma prática extremamente popular e não apenas pelas obrigatórias cinco abluções diárias que asseguravam o estado de pureza imprescindível à maioria dos atos rituais. A função social que cumpriam foi igualmente determinante para a população em geral. Por outro lado, entre os estratos mais elevados da sociedade, os banhos atingiram um elevadíssimo nível de sofisticação, constituindo não só um momento fundamental da vivência cortesã como integrando, no ciclo restrito das elites governantes, o protocolo oficial (Jimenez Castillo; Navarro Palazón, 2009, p. 75). [Fig. 2]

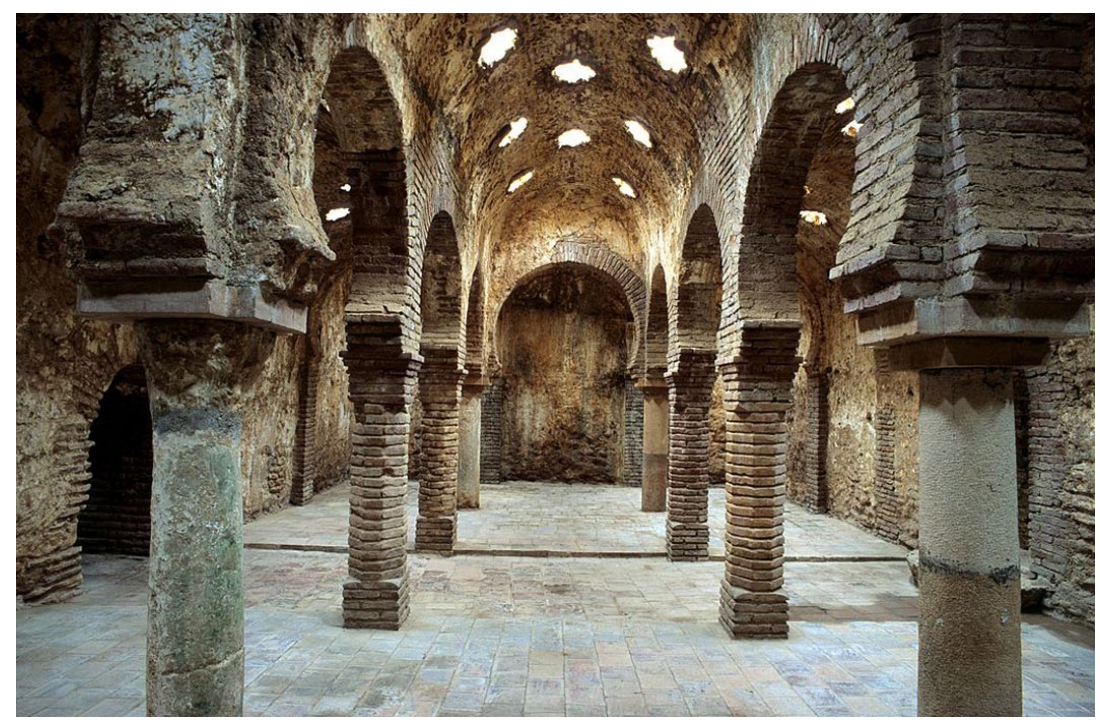

Fig.2 - Ronda (Espanha), Banhos islâmicos dos finais do século XIII.35. 
Não admira, por isso, que, privados e públicos, embora estes últimos sem a monumentalidade das grandes termas romanas, ${ }^{5}$ os banhos existissem onde quer que o ocupante muçulmano se tenha instalado.

Em número variado, por forma a servirem a totalidade dos bairros, localizavamse preferencialmente junto às portas da medina ou nas artérias mais centrais, em qualquer dos casos em pontos onde o abastecimento de água estivesse assegurado. Diferenciados por género ou oferecendo turnos distintos para homens e mulheres, os banhos tomavam-se cobertos por panos de linho podendo, de acordo com a maior disponibilidade económica, dispor do auxílio de um criado que transportasse os baldes de água e massajasse o corpo com unguentos, usando-se para tal cubículos mais ou menos privados. Excedendo o preceito religioso e claramente inscritos nos códigos de sociabilidade, por entre distrações e cantares, associavam ao prazer da água e do vapor o costume de comer.

Ao contrário dos inúmeros casos sobreviventes em território espanhol (Granada, Toledo, Córdova, Ronda, Múrcia, Elche, Jaén, Jerez e Gibraltar, etc), entre nós, o único até hoje conhecido é o de Loulé, descoberto em 2006 em pleno centro histórico. Refira-se que a estrutura se encontra ainda em estudo, sobretudo porque, em janeiro de 2014, foram identificados novos vestígios no Largo D. Pedro I, fronteiro ao edifício da Casa das Bicas onde se situam os tanques primeiramente escavados. $O$ reconhecimento destes novos elementos, entre eles um vestíbulo e umas possíveis latrinas, para além de denunciar um equipamento de dimensões superiores e maior complexidade formal parece, porventura, indiciar que aí se situaria a zona seca dos banhos. ${ }^{6}$

É essa disparidade de vestígios entre os dois países que justifica, por um lado, o fraco investimento português na temática, por outro, que seja a historiografia espanhola a responsável pelo conhecimento amplo e circunstanciado destas estruturas balneares.
O movimento da Reconquista cristã e a transferência do domínio político para as mãos dos conquistadores de matriz francoromana - representando a tantos níveis um corte civilizacional (Trindade, 2013, p. 61-81) - trouxe de novo um decréscimo acentuado ao número de equipamentos balneares. 7 Mas de forma alguma determinou o seu desaparecimento: o estigma que Michelet lançou sobre a Idade Média, "nenhum banho durante mil anos" (1863, p. 117), está hoje definitivamente ultrapassado. Os novos senhores não só usaram as estruturas existentes nas cidades conquistadas, como construíram muitas outras. $^{8}$

Este pressuposto, hoje amplamente demonstrado, implica que na abordagem ao tema um outro conceito seja revisto: a atitude condenatória do cristianismo face ao banho. I Igualmente questionável no processo analítico é a associação imediata entre a prática do banho e cuidados de higiene, noção aplicável à contemporaneidade, mas profundamente redutora quando transposta para a Idade Média.

Quanto ao posicionamento da Igreja, neste como em muitos outros aspetos relativos à conduta do homem - casamento, divórcio, concubinato ou sexualidade - o seu discurso no decorrer da longa Idade Média esteve longe de ser uníssono, menos ainda linear (Mattoso, 2009, p. 16). Em primeiro lugar porque sempre se registou uma distância significativa entre as considerações teológicas discutidas nos concílios e as pragmáticas impostas ao comum dos fiéis, necessariamente mais simples e moderadas. Em segundo lugar porque, sobretudo a partir da reforma gregoriana e até ao século XVI, o discurso endureceu, evoluindo a par e passo com a cada vez mais assumida vontade de regular e controlar os comportamentos e por eles a moral cristã. Mas mesmo quando em finais da Idade Média a tolerância para com determinados comportamentos diminuiu ou mesmo desapareceu, importa avaliar, num balanço nem sempre fácil entre normativa e prática, o efetivo alcance dos ditames mais severos. São 
amplamente conhecidas as dificuldades em impor os novos modelos de conduta, quer no seio da própria comunidade religiosa, ${ }^{10}$ quer, por maioria de razões, entre os fiéis. Efetivamente, a normativa eclesiástica oficial não foi assumida de forma passiva por toda a sociedade laica: como sublinhou J. Mattoso (2009, p. 23), o que devia ser, nunca foi confundido com o que realmente era, dentro do princípio de que todo o preceito deve ser adaptado à ação. A moral eclesiástica, pensada em primeiro lugar para os monges e por isso inflamada e radical no combate aos pecados da carne e da luxúria - a que o banho não deixaria de se associar - , não foi necessariamente coincidente com as práticas da sociedade. ${ }^{11}$ [Fig. 3] ser dado aos doentes com a escassez de uso permitida aos que gozam de plena saúde, particularmente quando jovens. ${ }^{12} \mathrm{~A}$ ideia de que os banhos aliviavam a tristeza e melancolia, causas principais de todas as doenças prolongadas, manter-se-ia por toda a Idade Média, dela voltando a fazer eco Tomás de Aquino (Aquino, 1989, p.

321-322) ou, entre nós, Frei Paio de Coimbra para quem o equilíbrio do corpo dependia da contenção alimentar, do exercício e dos banhos (Mattoso, 2011, p. 372).

Outros indícios de natureza diferente, corroboram a prática do banho, total ou parcial, entre o clero: na famosa planta de Saint Gaal, ${ }^{13}$ desenhada na primeira metade do século IX, assinalam-se pelo

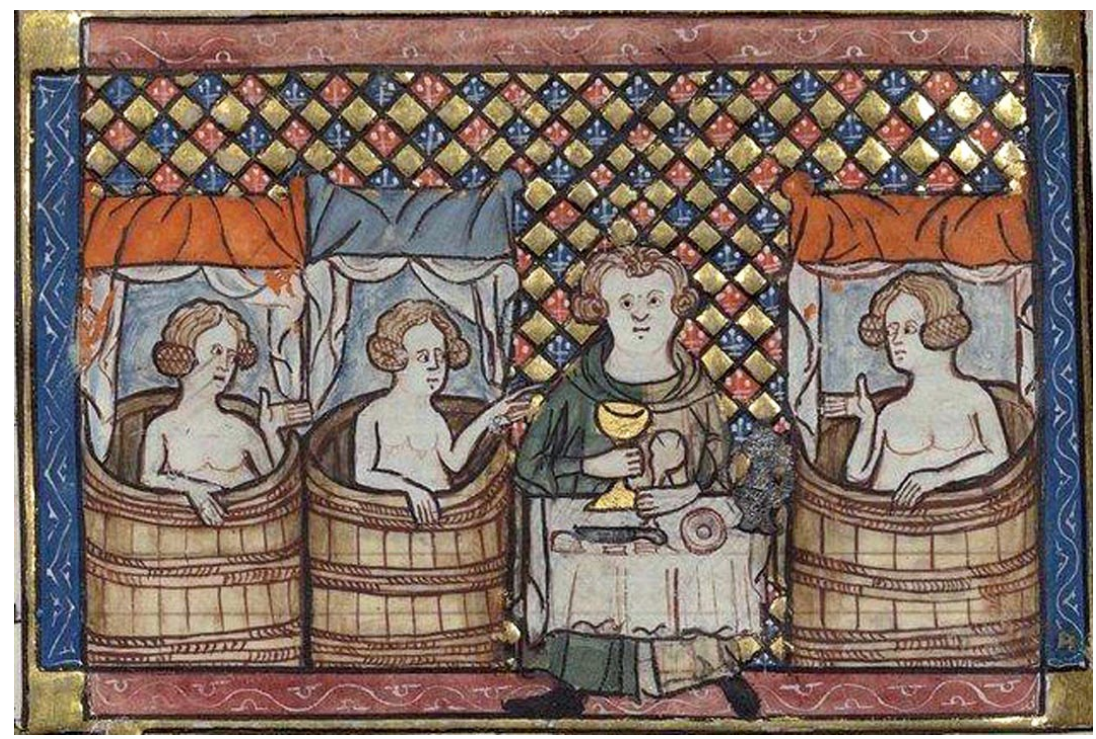

Fig.3 - Dits de Watriquet de Couvin, século XIV. Paris, BnF, Bibliothèque de l'Arsenal, 3525 , f. 84 v.

Neste âmbito da(s) atitude(s) do cristianismo face à prática do banho, alguns exemplos de natureza modelar e até mesmo vinculativa demonstram o intervalo prevalecente entre uma condenação liminar e a tolerância perante um uso controlado ou, sobretudo, se justificado por razões terapêuticas, aspeto particularmente evidente nas regras de Santo Agostinho e $S$. Bento: se o primeiro recomenda o banho aos enfermos, mesmo que contra a vontade do próprio, o segundo é mais peremptório, contrapondo a frequência com que deve menos 4 áreas destinadas a banhos: junto ao dormitório dos monges, no noviciado, na casa do Abade e, como não podia deixar de ser, na enfermaria; num outro levantamento, dos raros que de cronologias tão recuadas lograram sobreviver, executado em torno de 1150 com o objectivo de registar todo o sistema de águas e canalização de chumbo da catedral de Canterbury, estão igualmente marcados os balneários, em edifício isolado e especialmente destinado para o efeito. ${ }^{14}$ Para o mosteiro de Cluny, finalmente, sabe- 
se que a área de banhos consistia numa estrutura com doze células abobadadas, cada uma delas contendo uma banheira de madeira (Négrier, 2011 , p. 119). A reduzida dimensão, tendo em conta a comunidade monástica que servia, justificase facilmente pelo facto de a regra obrigar a apenas dois banhos completos por ano, por ocasião das grandes festividades litúrgicas: um pelo Natal, outro pela Páscoa (Ariès \& Duby, 1990, p. 519).

Estes e outros exemplos permitem-nos, por um lado, comprovar a prática do banho, por outro, identificar dois vectores fundamentais do discurso religioso oficial: o reconhecimento das suas qualidade terapêuticas; a condenação do excesso e do relaxamento de costumes implícito, associando o prazer do banho ao pecado da luxúria, pecado cuja gravidade o tornava prioritário no ato de confissão. Em síntese, quando a igreja discute a prática do banho fá-lo ou pela sua legitimação terapêutica, ou enquanto prática a moralizar.

Raramente a higiene é a razão invocada. Neste âmbito estrito, a sociedade medieval, religiosa ou laica, parece ter considerado suficiente o cuidado com as partes visíveis do corpo: rosto e mãos, aquelas que o vestuário deixava a descoberto. O rosto lavava-se todas as manhãs, com água fria, olhos e boca incluídos. A lavagem das mãos era mais frequente, particularmente antes de qualquer refeição. Em qualquer corte senhorial, nenhum banquete começava sem que um cortejo de criados trouxesse aos convivas um conjunto de gomis e bacias de "levar água às mãos", objetos frequentemente realizados em metais preciosos e com um acrescido cuidado estético. ${ }^{15}$ [Fig. 4] A mesma lavagem era prática obrigatória nos mosteiros, como desde cedo impusera S. Bento de Núrsia, ${ }^{16}$ ainda que as comunidades religiosas substituíssem as bacias pelos lavabos, estrategicamente colocados à porta dos refeitórios.

Cura ou pecado, portanto. A primeira é facilmente explicável à luz dos fundamentos da medicina greco-romana, hipocrática e

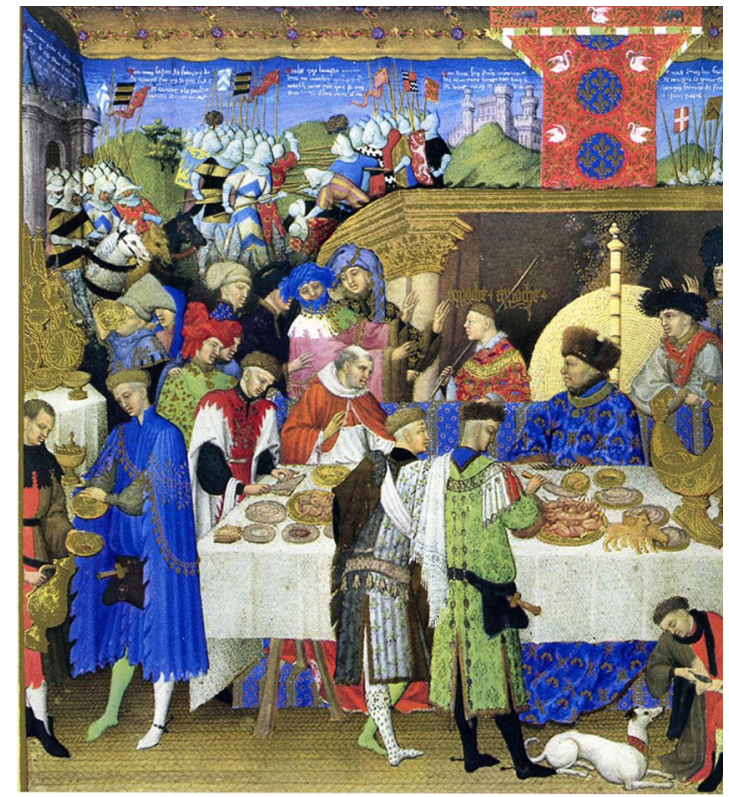

Fig.4 - O ritual do "lava mãos" durante um banquete. Irmãos Limbourg, Les tres riches heures du Duc de Berry (mês de Janeiro). Chantilly, Musee Conde (pormenor).

galénica essencialmente.

Preservados, traduzidos e ampliados por autores árabes, com destaque para Haly Abbas ou Avicena, esses fundamentos introduziram no ocidente cristão (Riera Palmero, 1998) a noção de medicina preventiva e o conceito de harmonia entre o homem e o meio ambiente. $A$ isso se deve o sucesso do banho. De facto, o equilíbrio entre as excreções e retenções dos humores, no caso do sangue, sémen e suor, conseguia-se, respetivamente, através da sangria, do coito e do banho. Ou seja, o banho é medicalizado. E a igreja, diretamente implicada na transmissão do saber clássico e árabe, é naturalmente a primeira a deixar-se persuadir pelas qualidades medicinais da água (Cifuentes \& Carré, 2009). [Fig. 5]

Resta justificar o discurso paralelo da condenação.

Alteradas as concepções de higiene clássicas e privados da sofisticada engenharia romana ou da obrigatoriedade dos preceitos religiosos islâmicos, os cristãos medievais banharam-se seguramente menos que os seus antepassados. Mas nem 


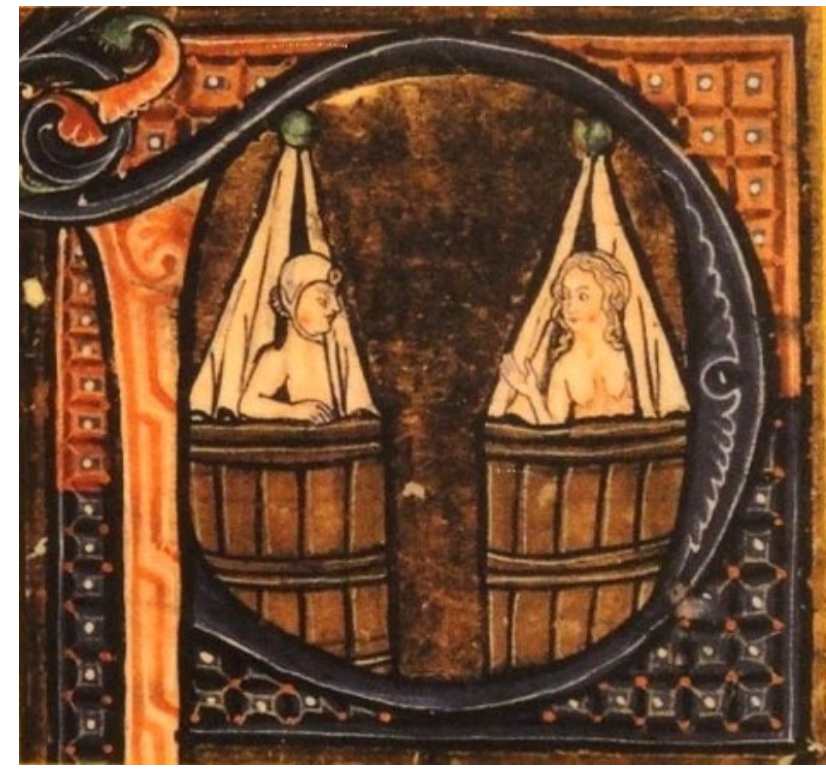

Fig.5 - lluminura representando o banho terapêutico. Aldobrandino da Siena, Regime dei Corpi ou Li livres dou sante, século XIII. Londres, British Library, Sloane MS 2435, inicial do capítulo VIII.Janeiro). Chantilly, Musee Conde (pormenor).

com menor prazer. Nos banhos públicos, a linha que separou o simples prazer da água e da convivialidade da volúpia e licenciosidade foi por vezes muito ténue. Demasiado ténue na perspetiva da igreja.

Efetivamente, tomava-se banho em conjunto, socializando. Fosse separando os géneros, fosse de forma conjunta. A proibição que a igreja fez incidir sobre o banho misto terá tido uma aplicação relativa podendo comprovar-se um pouco por toda a Europa, sobretudo no centro, norte e leste onde os rigores do clima tornavam as estufas particularmente procuradas e banais. Aliás, das assimetrias culturais norte-sul é prova a surpresa de Poggio Bracciolini, Secretário do papa João XXIII, quando em 1416 esteve em Baden. A descrição que deixou dos banhos públicos, mistos e abertos a todos, da nudez completa ou das roupas ligeiras, de como assim cantavam, comiam e jogavam numa convivialidade inocente, expressa bem como de todos os presentes, o italiano era o único a quem tal causava assombro e agitação (Ariès \& Duby, 1990, p. 593-596).

França, em posição intermédia, permite aferir como, pese embora o movimento registado no decorrer dos séculos XIV e XV a favor da separação, tal nunca se tornou uma prática universal. Em muitas situações, porém, estabelece-se uma regra de alternância, fixando-se dias ou horas para cada um dos géneros.

Foi separadamente que Dürer os retratou comprovando como mesmo na Alemanha conviveram os dois tipos de banhos. [Fig. 6] Na Península lbérica é provável que a separação fosse a prática mais comum: determinada nos foros de Valência e de Úbeda, surge igualmente contemplada nos Foros e Costumes de Riba Côa, estabelecendo-se os domingos, terças e quintas para as mulheres, os restantes dias para os homens (Tavares, 2014, p. 98-99).

Estas mesmas normas permitem-nos aferir a sua popularidade impondo uma abertura diária, de segunda a domingo. Aliás, um outro testemunho corrobora-o de forma ainda mais significativa, mesmo que circunscrito ao universo feminino: trata-se de uma passagem do Foro Real, originalmente escrito para a realidade castelhana mas traduzido e incorporado no direito português, onde se diz que "toda mulher possa testemunhar em coisas que 
forem feitas ou ditas no moinho, no forno, no banho, no rio ou na fonte" (Ferreira, 1987, Livro II, p. 432). Note-se como o banho é tratado em pé de igualdade com tarefas tão comuns e essenciais ao quotidiano como moer o cereal, cozer o pão, lavar a roupa ou ir buscar água à fonte.

Um outro indicador de que a prática do banho tinha suficiente procura era o facto de constituir um negócio lucrativo e cobiçado. Por isso interessava aos poderosos: no foral de Loulé, outorgado em 1266, D. Afonso III fez questão de mencionar que a exploração dos banhos (a par com a dos açougues e fangas) era reservada à coroa (Martins, 1989, p. 25); em Setúbal, em 1341, o mestre de Santiago procurou garantir para si o monopólio dos banhos ano de 1392, o direito de administração de uns banhos em Alfama é a razão de uma contenda entre os monges do Mosteiro de Alcobaça e o Senado da Câmara, sendo a posse dos ditos reivindicada pelos cistercienses (Silva, 2008, p. 86).

Equipamentos de sucesso, portanto, o que se explica pela componente social que lhes estava associada, sobretudo na esfera do quotidiano feminino. Porque a água era em primeiro lugar um prazer, o banho tornouse - ou simplesmente continuou a ser um momento fundamentalmente lúdico, festivo e partilhado. Com os corpos total ou parcialmente imersos em água quente, conversava-se, ouvia-se música, bebia-se vinho e ingeriam-se alimentos vários.

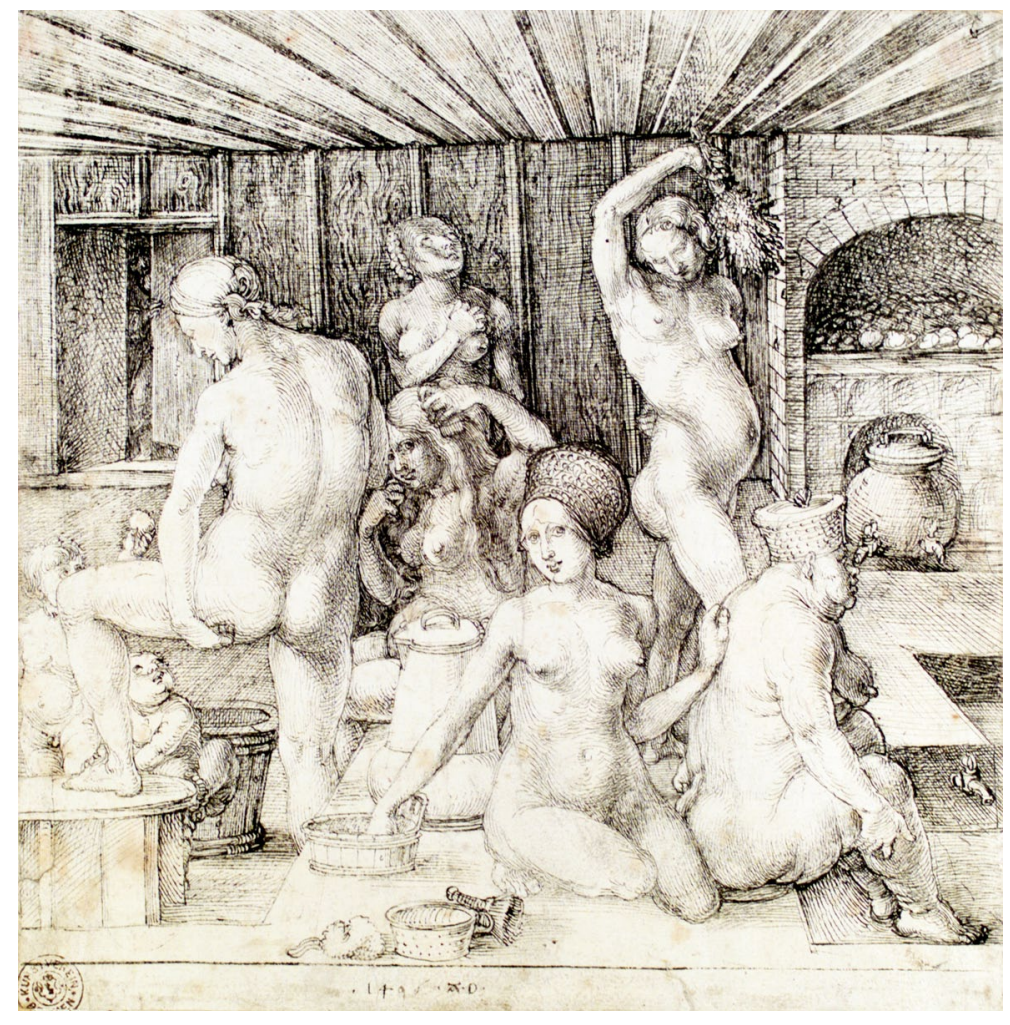

Fig.6 - Banhos públicos femininos. Albrecht Dürer, Banho de mulheres, c. 1496.

(Braga, 1998, p. 418). Nem mesmo o clero secular e regular rejeitava o investimento, por muito que condenasse a prática: dos três banhos existentes em Évora, uns, pelo menos, eram propriedade do Cabido da Sé (Beirante, 1995, p. 244) ${ }^{17}$; em Lisboa, no
De forma insistente, as muitas iluminuras medievais que retratam o banho associam a água ao prazer da comida e da bebida. Associação que igualmente se comprova para Portugal: num documento da Colegiada de São Pedro de Elvas, 
datado de meados do século XIV, as várias mulheres inquiridas relatam ser costume ir aos banhos públicos e aí comer e beber. ${ }^{18}$

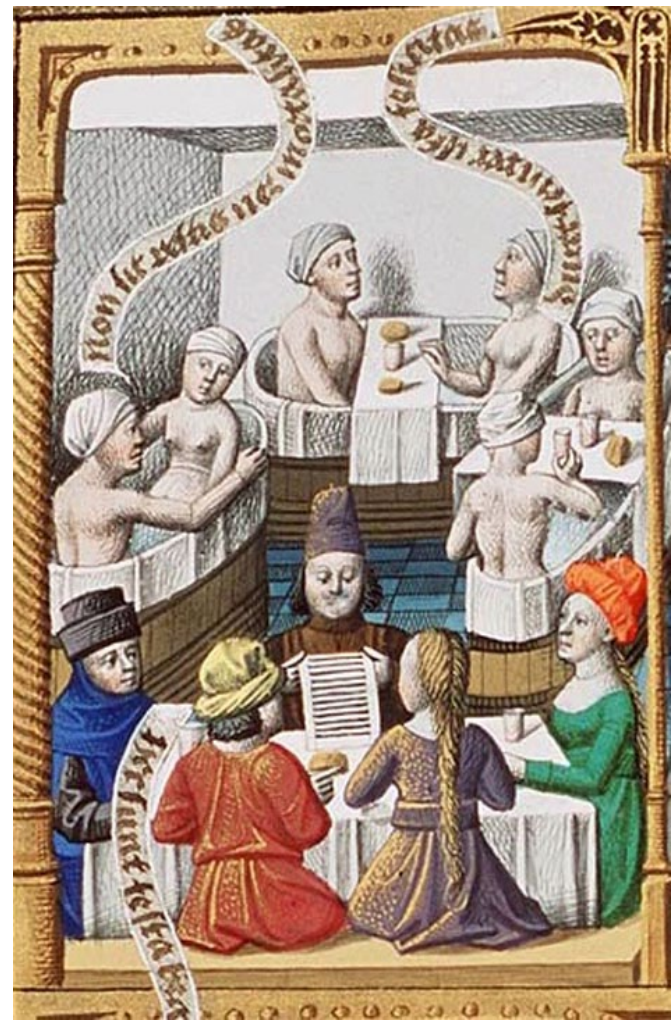

Fig.7 - lluminura representando os costumes pagãos em A cidade de Deus, de Santo Agostinho, c. 14751480. Haia, Koninklijke Bibliotheek, MMW, 10 A 11 , fol. $69 \mathrm{v}$

Aliás, este tipo de banho festivo,

convocando em simultâneo vários sentidos, foi uma prática transversal a todos os estratos sociais: ${ }^{19}$ na corte borgonhesa de Filipe o Bom e Isabel de Portugal, filha de D. João l, era prática comum que parte das celebrações decorressem nos banhos do palácio: os que Filipe ofereceu em dezembro de 1462 aos embaixadores do duque da Baviera, ficaram particularmente famosos pelos cinco pratos de carne então servidos (Gachard, 1876, p. 89). O mesmo ocorreu por ocasião do casamento do filho de ambos, Carlos o Temerário, com Margarida de York, tornando-se quase lendária a gigantesca piscina de metal encomendada, para cuja entrada no palácio teve de ser destruída uma parede.
Para a corte portuguesa, todavia, não se conhecem relatos que testemunhem práticas similares. As grandes festividades eram acompanhadas de torneios, justas e jogos de canas, caçadas, touradas, desfiles de mouros, judeus e selvagens, danças, momices e representações mascaradas. Mas nenhum banho de aparato deixou memória, no que parece estar de acordo com a moral rigorosa que $D$. João I e $D$. Duarte defendiam.

Inevitavelmente, o imaginário da água associado à nudez dos corpos traria para o centro da discussão a frágil fronteira entre um comportamento moderado e moralmente aceite e uma prática hedonista, excessiva e reprovável. Com efeito, entre os vários sentidos explorados pelo banho, a sensualidade e o erotismo foram aqueles que de forma mais vincada marcaram a literatura.

O banho era prelúdio indispensável de qualquer jogo amoroso, momento de sedução em que às mulheres, senhoras da água, cabia a função específica de lavar o corpo do companheiro (Ariès \& Duby, 1990, p. 364 e 518). Às qualidades estimulantes do banho $\neg$ - e intensificando-as - juntavase, como vimos já, o consumo de alimentos e bebidas várias. Em muitos casos, porém, tratava-se de produtos com qualidades afrodisíacas como o vinho doce, ovos moles com canela, predizes e faisões. Receitas que a própria medicina medieval legitimava aconselhando-as a casais com dificuldades de concepção (Cifuentes \& Carré, 2009, p. 220). A literatura é rica em descrições do banho como prática privada do casal, tomado no quarto junto à lareira e à cama, acompanhado do inevitável repasto. [Fig. 8]

Como expectável, a associação entre banho e sedução ou jogos libidinosos não se limitou à esfera privada sendo, em muitos casos, a nota dominante nos relatos dos banhos públicos e mistos. Agora, em clima de transgressão, real ou imaginada. Disso faz igualmente eco a literatura: Flamenca, a conhecida novela redigida na Aquitânia em finais do século XIII, tem os banhos públicos como o cenário de encontro do 


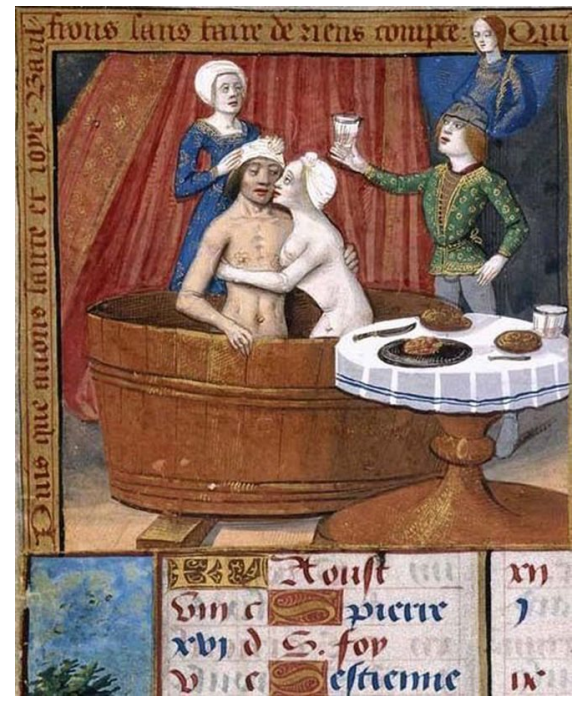

Fig.8 - lluminura de Jean Poyer (?), Libro de horas de Carlos $V$, Paris, finais do século XV. Madrid, Biblioteca Nacional de España, Cod. Vitr. 24-3, f. 10v

casal adúltero (Carré \& Cifuentes, 2007, p. 398).

Neste âmbito do confronto entre a discrição da prática privada e a exposição inerente ao uso público, a opinião expressa por Francesc Eiximenis, ${ }^{20} \mathrm{em}$ finais do século $\mathrm{XIV}$, é particularmente elucidativa da forma como a sociedade medieval encarou o banho, tanto mais quanto veiculada por um franciscano particularmente ativo na modelação de comportamentos: em privado e com moderação reconheceos como um prazer honesto, passível de ser praticado pelos príncipes e seus filhos; pelo contrário, enquanto prática pública e conjunta, reprova-os de forma peremptória pela dissolução moral a que dão azo, fruto do contacto sexual que promovem. É isso aliás que, ainda segundo o frade catalão, explica, por um lado, a frequência com que a eles recorrem as viúvas dissolutas, por outro, o perigo que representam para as donzelas (Eiximenis vol. 1, p. 206 e vol. 2, p. 396). [Fig. 9 e 10]

Banho, luxúria e prostituição seriam sempre uma associação inevitável (Vigarello \& Birrell, 1988; Rossiaud, 1988). Locais de prazer, os banhos confundem-se frequentemente com bordéis, tabernas e tavolagens, numa ambiência de transgressão e libertinagem amplamente registada nas iluminuras medievais. As mais representativas são as que ilustram as populares reedições da obra clássica Facta et dicta memorabilia onde a lascívia dos banhos romanos retratada por Valerius Maximus é transposta para os banhos públicos tardo-medievais. ${ }^{21} \mathrm{~A}$ turbulência que atraem, a permissividade e a ilegalidade com que, mesmo que nem
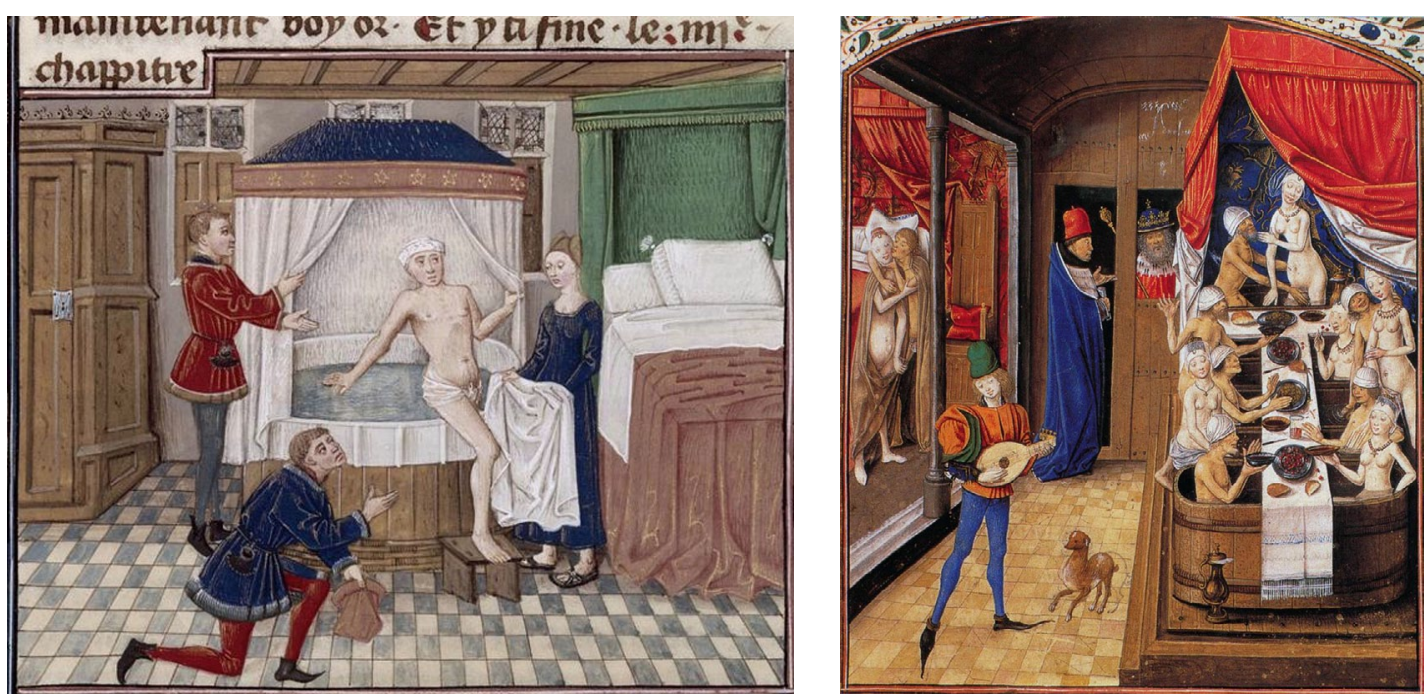

Fig.9 - lluminura do Mestre de Alexandre-Wauquelin, Facta et Dicta Memorabilia de Valerius Maximus, Coleção de Filipe o Bom, Borgonha, c. 1455. Paris, Bibliothèquenationale de France (BnF), Francais $6185 \mathrm{Fl} 284$. Fig. 10 lluminura do Mestre de António da Borgonha (filho de Filipe o Bom) em Factorum et Dictorum Memorabiliorum de Valerius Maximus, c. 1470. Berlin, Staatsbibliothek, Ms. Dep. Breslau 2, vol. 2, fol. 244. 
sempre justamente, são rotulados, explica a permanente vigilância ao mesmo tempo que potencia o ataque da igreja e das autoridades urbanas.

No que toca à realidade portuguesa, o estudo realizado por Ângela Beirante sobre as mancebias não permitiu concluir que os banhos fossem utilizados como locais de prostituição (Beirante, 2008a, p. 24). Além fronteiras, porém, conhecem-se inúmeros casos em que a presença de prostitutas era objecto de regulação, restringindo-lhes a frequência, separando-as dos demais utilizadores. Foi assim no caso de Marselha, onde se lhes reservava a segunda feira (Otis, 1985).

Refira-se, a este propósito, que outros grupos minoritários da sociedade medieval foram sujeitos a tratamento idêntico: os judeus, também em Marselha, viam o seu uso limitado à sexta feira. Esta separação por credo religioso foi igualmente praticada na Hispânia, sendo referida nos foros de Placência, Béjar, Sabiote e Úbeda, por exemplo.

Mas o que se sabe afinal sobre estas estruturas?

De Setúbal a Castelo Rodrigo ou do Porto a Faro, ${ }^{22}$ existem registos de balneários, ainda que lamentavelmente sejam apenas de carácter toponímico. A sua procura e popularidade transformou-os em referentes materiais da paisagem urbana dando 0 nome a postigos, porta e ruas. ${ }^{23}$

Muito mais raras, quase fortuitas, são as referências à sua materialidade. Dos da Mouraria de Lisboa, explorados por um cristão e servindo a utilizadores de ambos os credos, sabe-se apenas que tinham "quatro portais de casas". Fechados em finais do século XIV, foram depois transformados em habitação privada (Barros, 2007, p. 232).

Para os existentes em Évora a informação é um pouco mais generosa: os da Rua dos Mercadores, explorados pelo cabido, tinham pelo menos uma divisão abobadada, uma adega e um quintal com poço e árvores (Beirante, 1995, p.
244). Outros, situados numa travessa entre a Rua do Raimundo e a dos Mercadores e ainda em uso em 1494, constavam de três compartimentos ou casas: uma com sobrado, outra servindo de adega, a terceira como "casa da fornaça em que poem fogo aos banhos e he de quatro varas de longo e outras tantas de ancho" (Carvalho, 2004, pp. 37-138). Também estes tinham o seu quintal.

Em Lisboa, junto ao Chafariz d'El-Rei, existiam em 1468 umas casas e banhos "com sua caldeira e aparelhos que a eles pertenciam" (Silva, 1939, p. 152).

Este magro conjunto de descrições coloca-nos perante estruturas de pequena dimensão, sem grandes especificações técnicas. Talvez uma abóbada para evitar o gotejar da condensação; um forno, necessariamente, para aquecer a água; a imprescindível adega! Nada que as distinga particularmente do casario envolvente. Discretas e anónimas, distanciam-se das estruturas grandiosas e de vocação propagandística erguidas na antiguidade ou dos requintes técnicos e decorativos do Islão, com recurso a abóbadas perfuradas, sistemas de tubagem no interior das paredes e hipocaustos subterrâneos. Aliás, nenhuma referência a tanques e piscinas. O banho simplifica-se pela supressão de diferentes temperaturas: as águas tépidas e frias desaparecem, substituídas em exclusividade pelo banho quente.

É esta simplificação geral do banho, sem necessidade de recorrer a formasarquitectónicas especificas e cuidadas que certamente explica o seu anonimato, por um lado, desaparecimento, por outro. Note-se como no caso dos banhos islâmico, foram justamente as especificidades técnicas e construtivas exigidas pelas zonas húmidas - grossas e sólidas paredes capazes de sustentar as abóbadas e manter o calor - que explicam a sua resistência ao tempo, bem como o seu reconhecimento por entre o restante casario (Jimenez Castillo \& Navarro Palazón, 2009, p. 81 e 90).

Claro que a insuficiência de meios de 
condução e distribuição de águas à cidade medieval foi obviamente uma forte condicionante na definição do funcionamento dos banhos. Sem investimento significativo em aquedutos e redes de saneamento (Trindade, 2014), o abastecimento limitava-se quase tão só aos recursos hídricos locais como nascentes e poços que alimentavam fontes, tanques e chafarizes. Acrescia a água transportada no dorso de animais de carga ou pelos aguadeiros.

Talvez por isso, ao contrário das piscinas e tanques de alvenaria característicos dos balneários romanos e islâmicos, o sistema medieval tivesse que recorrer essencialmente a selhas de madeira, para as quais a água quente era transportada em baldes. Ora acontece que a banheira é uma simples peça de mobiliário sem qualquer influência determinante na arquitetura. Retratadas com insistência nas iluminuras da época, num modelo sempre idêntico em que só o tamanho parece diferente, oferecendo a possibilidade de banhos individuais, duplos ou colectivos, surgem guarnecidas com arcos de ferro de onde pendiam cortinas ou dosséis com a função de conservar a temperatura e o vapor. Praticavam-se infusões de plantas odoríferas e dispunham-se os alimentos em tábuas assentes sobre os bordos da selha. Em determinados estabelecimentos, não necessariamente associados à prática da prostituição, existiam compartimentos de repouso com camas providas de cobertores onde, para além da sudação, o corpo era friccionado com óleos vários.

Imersão, vapores, calor, transpiração, tudo o que até então era associado a prazer adquire, a partir do século $\mathrm{XV}$, uma conotação negativa pelos perigos implícitos. A explicação reside na crença da permeabilidade do corpo, um princípio mecânico simples: os poros funcionam nos dois sentidos. Quando abertos não só deixam sair os vigores, como, sobretudo, permitem a entrada dos males. E o mal, no século XV, tornou-se endémico: não houve uma única década em que não se registasse um ou mais surtos de peste, de epidemias várias, todas elas mortíferas. ${ }^{24}$ Razão por que tudo o que contribuísse para abrir os poros devia ser evitado: o "Regimento proveitoso contra a pestenença", alertava para três situações em que a temperatura do corpo subia: "quando desordenados em luxúria e coito, em trabalho físico e na prática ameúde dos banhos" (Machado, 2004, p. 28).

Perigos que foram transmitidos em primeiro lugar pelos discursos inflamados dos pregadores, mas que, logo depois, foram difundidos pelas autoridades. Os banhos não resistem à dupla ofensiva, moral e médica. No século XVI o encerramento torna-se oficial e sistemático.

Erasmo testemunha-o em 1526: "há 25 anos nada estava mais em voga do que os banhos públicos: hoje tudo isso desapareceu, a nova peste ensinou-nos a dispensá-los" (Vigarello \& Birrell, 1988). Também Lúcio Marineo Sículo, em 1500, atribui o abandono dos 4 banhos que então funcionavam em Toledo ao medo que todos tinham das enfermidades (Jimenez Castillo \& Navarro Palazón, 2009, p. 78).

Perde-se o prazer da água, transforma-se a noção de higiene. A partir de quinhentos impera a limpeza a "seco" através da renovação da roupa branca usada junto ao corpo. O ideal é manter o corpo limpo através de uma segunda pele que absorva as impurezas expelidas e mantenha uma certa proteção dos ares malsãos. É o branco dos colarinhos e punhos que se converte num código social, cabendo-lhe sugerir o que não se vê. A roupa branca limpa como a água, mas sem os perigos dela (Vigarello, 1996).

Água que agora, paradoxalmente, chega em muito maior abundância às cidades. Ao mesmo tempo que a práticado banho, privada ou pública, é banida dos hábitos ocidentais, verifica-se um renovado investimento por parte do poder régio nos sistemas de captação e distribuição de água à população. Em Portugal, D. João II, D. Manuel e D. João III são os responsáveis pela mudança de paradigma, promovendo, numa atitude de clara inspiração clássica, a edificação 
dos grandes aquedutos de Setúbal, Évora ou Elvas (Trindade, 2014). Muitos outros, em Miranda do Douro, Aveiro, Torres Vedras, Óbidos, Coimbra e Tomar são igualmente (re)erguidos em Quinhentos. Não será já, todavia, a prática do banho a deles beneficiar.

\section{Notas}

(1) Eginardo e Alcuino testemunham o profundo apreço de Carlos Magno pelas águas termais de Aachen, a velha Aquisgrana romana. A historiografia, aliás, tende a atribuir-lhes um peso importante na escolha do local para sede da corte imperial (Nicoud, 2002, p. 14). Quanto às Aquae Calidae de Bath, continuaram a ser frequentadas no decorrer de toda a ldade Média. No século XII, por entre as dependências da catedral, continuava a ser famoso o "Banho do Rei", abastecido pela principal das 3 nascentes da região, explorada desde a época romana. O banho, responsável pela vinda de gentes de toda a Inglaterra, é detalhadamente descrito pelo bispo Roberto, em 1138 (Cunliffe, 2002, p. 62).

(2) Muitas outras termas seriam igualmente exploradas. Apenas a título de exemplo, na descrição que faz da cerca de Lisboa e das suas portas, Al-Himyari [1002 - 1085] menciona a Porta da Fonte Termal (mais tarde Porta de Alfama), aberta junto ao mar. Quanto à estrutura balnear propriamente dita, refere apenas as coberturas abobadadas, as nascentes de onde brotava água quente e fria e a forma como ficavam submersas quando a maré subia (Silva, 2008, p. 96).

(3) Apesar do seu carácter medicinal não pode deixar de se fazer menção à ampla e complexa estrutura descoberta em 2006, no Largo do Arrabalde de Chaves, no âmbito das obras de construção de um parque de estacionamento (Carneiro, 2013, p. 293-802).

(4) Sobre os banhos na sociedade islâmica ibérica em especial, mas com referências fundamentais para a prática do banho na sociedade medieval em geral, veja-se o excelente trabalho de P. Jimenez Castillo e J. Navarro Palazón, "Arqueologia del baño andalusi: notas para su comprensión y estudio" em que, para além de uma síntese sobre o que a historiografia/arqueologia espanhola pôde já apurar e de uma ampla bibliografia dedicada ao tema, os autores apresentam uma importante proposta de análise tipológica (Jimenez Castillo; Navarro Palazón, 2009).

(5) Tal como os banhos romanos, os islâmicos incluíam necessariamente um vestiário ou apoditerium (al-bayt al-maslaj) e vários tanques com águas a diferentes temperaturas: de água fria (al-bayt al-bârid), de água tépida (al-bayt al-wasti) e de água quente (al-bayt al-sajûn) correspondente ao caldarium romano e que, tal como este, ocupava sempre o local mais próximo da caldeira. Entre as diferenças registadas entre banleários romanos e islâmicos, destaca-se uma diminuição geral da dimensão e, sobretudo, uma maior simplicidade funcional, deixando de se associar à estrutura balnear propriamente dita espaços destinados a bibliotecas e ginásios. Uma outra diferença essencial é a substituição das grandes piscinas por tanques de onde se tirava a água com um balde, pois a imersão deixaria a água impura.

(6) Obras na Zona Histórica levam a novas descobertas nos Banhos Islâmicos de Loulé http://www.cm-loule.pt/noticias/5668/obrasna-zona-historica-levam-a-novas-descobertasnos-banhos-islamicos-de-loule.aspx, acedida a 21.08.2014.

(7) O Repartimento de Valência demonstra como apenas cinco dos mais de vinte existentes na cidade resistiram à Reconquista (Jimenez Castillo \& Navarro Palazón, 2009, p. 77).

(8) Burgos, Jaca, Canfranc, Sanguesa, Estela, San Sebastian, Cidade Rodrigo, Placência, Alba de Tormes e Sória são alguns dos exemplos possíveis (Torres Balbás, 1954, p. 47). Entre os mais conhecidos contam-se os Banhos de Girona (século XII), os do Convento de Santa Clara de Tordesilhas (Valladolid), erguidos após 1340 no que era originalmente um palácio de Afonso $\mathrm{XI}$, e os Banhos do Almirante, em Valência, dos primeiros anos do século XIV.

(9) Se a igreja cristã dos primeiros tempos foi ambivalente relativamente aos banhos, foi quase unânime no que toca aos jogos, ginásios e palestras, progressivamente desaparecidos e, finalmente, interrompidos após cerca de 1000 anos de tradição (Smith, 2007, p. 124).

(10) A dificuldade de controle dos desvios face à norma oficial fica bem patente quando se toma por exemplo a prática da barregania clerical, ainda bem arreigada no decorrer do século XII. Aliás, em finais de quatrocentos, de acordo com o testemunho do arcebispo D. Luís Pires, a barregania continuava a ser uma realidade entre clérigos, apenas suportada se dissimulada 
(Oliveira, 2011, p. 336-337).

(11) A análise que Resende de Oliveira faz da sexualidade na Idade Média portuguesa, é para nós essencial, até pela proximidade do tema. Das sua conclusões destacamos a aparente liberdade de costumes sexuais que caracterizou os séculos XIII e XIV. Efetivamente, para além de demonstrada em meio cortesão pelas cantigas de escárnio e maldizer, essa liberdade é corroborada pelo discurso de condenação do Bispo de Silves. Não por acaso, os manuais dos confessores, amplamente divulgados, aconselhavam a começar a confissão pelo pecado da luxúria onde se englobava o conjunto dos pecados sexuais. Todos os indicadores apontam para que, até ao século XIV, o impacto das normas eclesiásticas tenha sido pouco significativo (Oliveira, 2011 , pp. 324-347).

(12) Regra de Santo Agostinho Cap. 5 , art 5 e Regra de São Bento, cap. 36 - Dos Irmãos enfermos.

(13) Carolingian Culture at Reichenau \& St. Gall. Codex Sangallensis 1092: content and context. University of California Los Angeles, University of Virginia, and University of Vienna, 2012, http:// www.stgallplan.org, acedido em Julho de 2014. (14) Eadwine Psalter, Trinity College, Cambridge, Ms R 171 f.285.

(15) No inventário e contas da casa de D. Dinis, datado dos anos entre 1278 e 1282 contabilizamse 10 "bacias de levar água às mãos" (Freire, 1916).

(16) Embora também prescrito pela regra beneditina, o uso do "lava-pés", justifica-se muito mais pela forte carga simbólica associada do que por preocupações puramente higiénicas. Praticado em todo o mundo antigo como sinal de hospitalidade, ganhou novas conotações ao ser incorporado pelo cristianismo: ato piedoso e de humildade por parte de quem o pratica, convoca a pureza da alma de quem o recebe, naquele que é afinal o princípio do baptismo.

(17) Que tal se verificou até muito tarde, mesmo quando as diretivas da igreja contra o banho endureceram, comprova-se pelo inventário dos bens do convento de Santo Domingo el Real, em Toledo, datado de 1460, onde não só fica bem patente a posse da propriedade como o cuidado em obrigar o arrendatário a arranjar o forno para que continue servindo como banhos (Passini, 2006, p. 45).

(18) Informação cedida por Luís Filipe Oliveira, e que muito agradecemos. Biblioteca Municipal de Elvas, Pergaminhos da Colegiada de São Pedro de Elvas, $n^{\circ} 55$ Doc. Truncado, sem se conhecer o ano, mas de Outubro, 21, Elvas. Sentença de vigário de D. João, bispo de Évora, em demanda entre a Colegiada de S. Pedro, de um lado, Ale mouro e alguns cristãos do outro, sobre a casa dos Banhos, com inquirição de testemunhas, dizendo as mulheres ser costume ir aos banhos e aí comer e beber. Os acontecimento sobre os quais corre a demanda são situados em 1305 (Era de 1343).

(19) Em 1476, a cidade de Paris recebeu a rainha Carlota de Sabóia com 4 aparatosos banhos, ato que ao mesmo tempo que anunciava a prodigalidade do anfitrião, reforçava o prestígio e nobreza de quem os recebia (Vigarello, 1996, p. 27)

(20) O Lo Crestiá (ou "O Cristão", obra enciclopédica escrita em vernáculo com 13 volumes previstos mas de que apenas 4 chegaram a ser efetivamente escritos, os 3 primeiros e $012^{\circ}$ ) e o Libre de les Dones, são dois exemplos das obras normativas amplamente difundidas de Francesc Eiximenis [c. 1330-1409], a primeira encomendada por Pedro IV de Aragão, a segunda redigida a pedido da condessa de Prades, Sancha Jiménez de Arenós.

(21) Também as Sátiras de Juvenal, amplamente usadas na Idade Média, alimentaram esta ideia de que o uso frequente dos banhos era um sinal da perfídia feminina (Carré \& Cifuentes, 2007, p. 398).

(22) Sem pretensão de exaustividade, Porto, Alfaiates, Castelo Bom, Castelo Melhor, Castelo Rodrigo, Leiria, Santarém, Lisboa, Setúbal, Alcácer do Sal, Évora, Elvas, Loulé, Faro, Tavira, Castro Marim, são algumas das localidades onde se regista a existência de banhos. Marques, 1974, p.15. Nas localidades maiores podiam coexistir vários destes equipamentos, caso de Évora onde se sabe terem existido três (Beirante, 2008b, p. 185).

(23) É o caso do Postigo dos Banhos, no Porto, da Porta dos Banhos, em Lisboa ou da Rua dos Banhos, em Évora (Vereaçoens, 1980, p. 99; Silva, 2008, p. 96-97; Beirante, 1995, p. 130-131).

(24) $1348,1356,1384,1415,1423,1432,1435,1437-$ $38,1448,1458,1464,1477,1480-97$ são anos de epidemias, algumas, como as de 1348, 1384 e 1415, de peste bubónica.

\section{Bibliografia}

Aquino, T. (1989). Suma de Teología (2a ed.). Madrid: Biblioteca de Autores Cristianos. 
Barros, F. L. (2007). Tempos e Espaços de Mouros. A minoria muçulmana no Reino português (sécs. XII - XV). Lisboa: Fundação Calouste Gulbenkian - Fundação para a Ciência e a Tecnologia.

Beirante, A. (2008a). As mancebias nas cidades medievais portuguesas ( $1^{a}$ ed. 1985). O ar da Cidade. Ensaios de História Medieval e Moderna. Lisboa: Colibri.

Beirante, A. (2008b). Espaços Públicos nas cidades portuguesas medievais ( ${ }^{a}$ ed. 1993). O ar da Cidade. Ensaios de História Medieval e Moderna. Lisboa: Colibri.

Beirante, M. A. (1995). Évora na ldade Média. Lisboa: Fundação Calouste de Gulbenkian Junta Nacional de Investigação Científica e Tecnológica.

Braga, P. D. (1998). Setúbal medieval, (séculos XIIIXV). Setúbal: Câmara Municipal - Biblioteca Pública Municipal.

Carneiro, S. (2013). As termas medicinais romanas de Chaves. In José Morais Arnaud; Andrea Martins; César Neves (eds.), Arqueologia em Portugal 150 anos (pp. 293-802). Lisboa: Associação dos Arqueólogos Portugueses.

Carré, A. \& Cifuentes, L. (2007). Los baños en la literatura catalana medieval durante los siglos XIV y XV. In Armando López Castro \& María Luzdivina Cuesta Torre (eds.), Actas del XI Congreso Internacional de la Asociación Hispánica de Literatura Medieval (pp. 394-403 ). León: Universidad de León.

Carvalho, A. (2004). Da Toponímia de Évora: dos meados do século XII a finais do século XIV. Lisboa: Edições Colibri.

Cifuentes, L., \& Carré, A. (2009). Práctica social, saber médico y reflejo literario de la cultura del baño en el contexto catalan medieval. Anuario de Estudios Medievales, 39/1 EneroJunio, 208-209.

Cunliffe, B. (2002). Bath et ses bains au Moyen Âge. In Didier Boissevil (coord.), Le Bain: Espaces et pratiques. Médièvales, 43 (pp. 5569). Saint Denis: PUV.
Ariès, P. \& Duby, G. (dir.) (1990). História da Vida Privada. Da Europa Feudal ao Renascimento. Porto: Edições Afrontamento.

Eiximenis, F. (1986). Dotzè llibre del Crestiá (ed. de Curt Wittlin et al.). Girona: Col.legi Universitari de Girona - Diputació de Girona.

Ferreira, J. A. (1987). Afonso X. Foro Real (ed. e estudo linguístico). Lisboa: Instituto Nacional de Investigação Científica.

Frade H. \& Moreira, J.B. (1992). A arquitectura das Termas romanas de S. Pedro do Sul. Revista Espacio, Tiempo y Forma, Serie II, Historia Antigua, V, 515-544.

Freire, A. B. (1916). Inventarios e contas da casa de D. Dinis, (1278 - 1282). Archivo Historico Português, X, 41-59.

Gachard, L. (1876). Les comptes de Philippe le Bon, duc du Bourgogne. Collections des voyages des souverains des Pays-Bas, 1. Brussels: F. Hayez.

Jimenez Castillo, P. \& Navarro Palazón J. (2009). Arqueologia del baño andalusi: notas para su comprensión y estudio. In Jose Manuel Iglesias Gil (ed.), Actas de los XIX cursos monográficos sobre el Patrimonio Histórico. Cursos sobre el Patrimonio Histórico, 13 (pp. 71-113). Santander: Universidad de Cantabria.

Machado, B. (2004). Edição semidiplomática do Regimento proveitoso contra a pestenença. Revista de Letras, 3, Série II (pp. 21-42). Vila Real: Departamento de Letras da Universidade de Trás os Montes e Alto Douro.

Marques, A. H. O. (1974). A sociedade medieval portuguesa ( $3^{a}$ ed.). Lisboa: Livraria Sá da Costa.

Martins, I. P. (1989). O foral de Loulé de 1266. Loulé: Câmara Municipal.

Mattoso, J. (2007). D. Afonso Henriques. Lisboa: Temas e Debates.

Mattoso, J. (2009). A sexualidade na Idade Média. Naquele Tempo. Ensaios de História Medieval. Círculo de Leitores e Temas e Debates. 
Mattoso, J. (2011) O corpo, a saúde e a doença. In J. Mattoso (dir.), História da Vida Privada em Portugal. A Idade Média (pp. 348-374). Lisboa: Temas e Debates.

Michelet J. (1863). La Sorcière. Bruxelles-Leipzig: A. Lacroix, Verboeckhoven et Cie Éditeurs.

Négrier, P. (2011). Histoire du bain à travers les âges (fac-similé de lédition de 1925). Art Secrets Reprints.

Nicoud, M. (2002). Les Médecins italiens et le bain Thermal à la fin du Mouyen Âge. In Didier Boisseuil (coord.), Le Bain: Espaces et pratiques. Médièvales, 43 (pp. 13-40). Saint Denis: PUV.

Oliveira, A. R. de (2011). O Corpo: a sexualidade. In J. Mattoso (dir.) História da Vida Privada em Portugal. A Idade Média (pp. 324-347). Lisboa: Temas e Debates.

Otis, L. L. (1985). Prostitution in Medieval Society The History of an Urban Institution in Languedoc. Chicago: University of Chicago Press.

Passini, J. (2006). Los Baños y el Agua en Toledo. Baños árabes en Toledo. Los monográficos del Consorcio, 2 (pp. 31-36). Toledo: Consorcio de Toledo.

Riera Palmero, R. (1998). El influjo greco-árabe en la medicina latina medieval. In Miguel Ángel García guinea, (dir.), La Vida Cotidiana en la España Medieval (pp. 57-83). Madrid: Fundación de Santa Maria La Real - Ediciones Polifemo.

Rossiaud, J. (1988). Medieval Prostitution. New York: Blackwell.

Silva, A. V. da (1939). A Cerca Moura de Lisboa (2a ed.). Lisboa: Câmara Municipal.

Silva, C. G. da (2008). Lisboa Medieval: a organização e estruturação do espaço urbano. Lisboa: Colibri.

Smith, V. (2007). Clean: a history of personal hygiene and purity. Oxford University Press.

Tavares, M. A. S. (2014). Costumes e foros de Riba-
Côa: normativa e sociedade. (PhD Faculdade de Letras da Universidade de Lisboa).

Torres Balbás, L. (1954). Algunos aspectos del Mudejarismo Urbano. Madrid: Imprenta \& Editorial Maestre.

Trindade, L. (2013). Urbanismo na composição de Portugal. Coimbra: Imprensa da Universidade de Coimbra.

Trindade, L., (2014). A água nas cidades portuguesas entre os séculos XIV e XVI: a mudança de paradigma. In, M. M. Lozano Bartolozzi \& V. Méndez Hernán, (coord. y ed.), Patrimonio cultural vinculado con el agua. Paisaje, urbanismo, arte, ingeniería y turismo (pp. 363-376). Mérida: Editora Regional de Extremadura.

Vereaçoens, Anos de 1401-1449 (1980). O segundo Livro de Vereações do Município do Porto existente no seu Arquivo (nota prévia de J. A. Pinto Ferreira). Porto: Câmara Municipal.

Vigarello, G. (1996). O limpo e o sujo. Uma história da higiene corporal. São Paulo: Martíns Fontes.

Vigarello, G. \& Birrell, J. (1988). Concepts of cleanliness: changing attitudes in France since the Middle Ages. New York: Cambridge University Press. 